\title{
A short-term in vivo model for giant cell tumor of bone
}

\author{
Maurice Balke ${ }^{1,2^{*}}$, Anna Neumann ${ }^{3}$, Károly Szuhai ${ }^{4,5}$, Konstantin Agelopoulos $^{6}$, Christian August ${ }^{7}$, Georg Gosheger $^{2}$, \\ Pancras CW Hogendoorn ${ }^{4}$, Nick Athanasou ${ }^{8}$, Horst Buerger ${ }^{9}$ and Martin Hagedorn ${ }^{10,11}$
}

\begin{abstract}
Background: Because of the lack of suitable in vivo models of giant cell tumor of bone (GCT), little is known about its underlying fundamental pro-tumoral events, such as tumor growth, invasion, angiogenesis and metastasis. There is no existing cell line that contains all the cell and tissue tumor components of GCT and thus in vitro testing of anti-tumor agents on GCT is not possible. In this study we have characterized a new method of growing a GCT tumor on a chick chorio-allantoic membrane (CAM) for this purpose.

Methods: Fresh tumor tissue was obtained from 10 patients and homogenized. The suspension was grafted onto the CAM at day 10 of development. The growth process was monitored by daily observation and photo documentation using in vivo biomicroscopy. After 6 days, samples were fixed and further analyzed using standard histology (hematoxylin and eosin stains), Ki67 staining and fluorescence in situ hybridization (FISH).

Results: The suspension of all 10 patients formed solid tumors when grafted on the CAM. In vivo microscopy and standard histology revealed a rich vascularization of the tumors. The tumors were composed of the typical components of GCT, including (CD51+/CD68+) multinucleated giant cells whichwere generally less numerous and contained fewer nuclei than in the original tumors. Ki67 staining revealed a very low proliferation rate. The FISH demonstrated that the tumors were composed of human cells interspersed with chick-derived capillaries.

Conclusions: A reliable protocol for grafting of human GCT onto the chick chorio-allantoic membrane is established. This is the first in vivo model for giant cell tumors of bone which opens new perspectives to study this disease and to test new therapeutical agents.
\end{abstract}

\section{Background}

Giant cell tumor of bone (GCT) is an aggressive skeletal lesion typically located in the epiphyseal end of a long bone [1-3]. The tumor predominantly occurs in the third and fourth decade of life with a slight predilection for females [3-8].

GCT is characterized by locally aggressive growth usually leading to extensive bone destruction [9]. The biological behavior of the tumor is, however unpredictable, and attempts to histologically grade the tumors have failed [10-12]. At the genomic level however recurrent cases are characterized by random individual cell

\footnotetext{
* Correspondence: maurice.balke@gmail.com

'Department of Trauma and Orthopedic Surgery, University of WittenHerdecke, Cologne-Merheim Medical Center, Ostmerheimer Str., 200, 51109 Cologne, Germany

Full list of author information is available at the end of the article
}

aneusomy, while malignant cases show abnormalities at array CGH level [13].

GCT is characterized by the presence of numerous Cathepsin-K producing, CD33 +, CD14 - multinucleated osteoclast-like giant cells and plump spindle-shaped stromal cells that represent the main proliferating cell population [14-17]. The spindle-shaped mononuclear cells are believed to represent the neoplastic population and are characterized at the cytogenetic level by telomeric associations and a peculiar telomere-protecting capping mechanism [18]. Areas of regressive change such as necrosis or fibrosis as well as extensive hemorrhage are frequently present.

The treatment of choice is intralesional curettage and bone cement packing leading to a local recurrence rate of 10 to $40 \%$ [1,19,20]; treatment options are limited and recurrence rates are higher when GCT arises at a surgical inaccessible location (e.g. spine and sacrum). In 
addition, some GCT may rarely arise at multiple sites or undergo sarcomatous transformation. In about $2 \%$ of cases, patients develop lung metastases, which are thought to represent benign pulmonary implants that arise following vascular invasion [21-25].

The underlying pathobiology of GCT growth and development of these complications is unknown. There is no successful adjuvant treatment option, although there are reports of a limited effect on tumor growth following treatment with bisphosphonates [26,27] and anti-RANKL antibodies [28], agents that inhibit the formation and activity of the osteoclastic giant cells in the tumor.

Thus far, attempts to grow GCT in animal models as well as to derive suitable cell lines from primary tumors have failed. This has limited the study of pathobiology of GCT and the development of specific anti-GCT agents. To address this problem we have examined whether it is possible to establish the growth of GCT short-term in vivo in a chick chorio-allantoic membrane (CAM) assay.

The CAM is characterized by an extremely dense vascular network with large vessels situated within the somatic mesoderm and capillaries located within or directly under the splanchnic mesoderm. This doublelayer membrane develops by fusion of the chorion with the allantoic vesicle on embryonic day 4 - 5 [29]. Until hatching the CAM physiologically absorbs calcium from the shell, stores waste products and serves as a respiratory organ [30].

The CAM assay has been utilized as a model system for more than a century to demonstrate development of embryonic blood vessels, and to provide a host for the grafting of bacteria, viruses and embryonic tissue. In the last 25 years, the CAM assay has become established as a model for angiogenesis research; this has been used to provide highly reproducible models for aggressive and malignant tumors including glioblastoma and pancreatic adenocarcinoma [31,32].

The use of the CAM assay in bone tumor research has only been sporadically reported. We recently published the successful establishment of human osteosarcoma cell lines on a CAM assay and provided evidence that the MNNG-HOS cell line reproduces the key features of human osteosarcoma growth when grafted on the CAM [33]. This relatively simple experimental approach enables tumor growth and vascularization to be easily studied and permits the growth of tumors to be studied in an inexpensive way.

In this report, we present the results of successful establishment of human GCT in a CAM assay with emphasis on the morphological characteristics of the grafted tumors.

\section{Methods}

\section{Patients}

The patients included in this study had typical, histologically confirmed cases of giant cell tumors of bone (GCT). The mean age of the five male and five female patients was 29.8 years; eight of ten were localized in the extremities, one in the spine and one in the pelvis. Four were recurrent cases (see Additional file 1). All patients gave their written consent prior to tumor tissue isolation for research studies. All samples were handled in a coded fashion and the experiments were performed according to the local ethical guidelines.

\section{Giant cell suspension}

Cell suspensions isolated from GCT tissue of 10 patients were used in the experiment. Tissue samples were minced and incubated at $37^{\circ} \mathrm{C}$ in RPMI with $5-10 \mathrm{ml}$ DNAse (2200 KU/100 ml - Sigma-Aldrich, Germany; cat. no. DN-25-10MG) and 5-10 ml collagenase Type 2 (500 U/ml - PAA; Austria; cat. no. K21-240) for 3-8 hours. DNAse and collagenase solutions were mixed in equal parts. The homogenized tissue solution was centrifuged at $1200 \mathrm{rpm}$ for $5 \mathrm{~min}$ and the cell pellet was subsequently washed twice with RPMI 1640 (PAA Austria; cat. no. E15-840) supplemented with 10\% Foetal Bovine Serum FBS Gold (PAA Austria; cat. no. A15649) and 1\% penicilline/streptomycine (PAA Austria; cat. no. P11-010). This procedure was repeated four times.

\section{Freezing giant cell suspension}

After the last washing step, the cell pellet was re-suspended in CryoMaxx $\mathrm{S}$ freezing medium (PAA, Austria cat. no. J05-013 - approximately $50 \mu$ to $200 \mu \mathrm{l}$ cells per $\mathrm{ml}$ freezing medium). One $\mathrm{ml}$ suspension was frozen per cryotube (Nunc; Germany; cat. no. 368632). Finished vials were frozen overnight at $-70^{\circ} \mathrm{C}$ in a freezing container (NALGENE ${ }^{\circledR}$ Labware, Hereford, United Kingdom Cat. No. 5100-0001) and stored in liquid nitrogen.

\section{Thawing giant cell suspension}

Cell culture medium RPMI 1640 (PAA Austria; cat. no. E15-840) supplemented with 10\% Foetal Bovine Serum FBS Gold (PAA Austria; cat. no. A15-649) and 1\% penicilline/streptomycine (PAA Austria; cat. no. P11-010) was preheated at $37^{\circ} \mathrm{C}$ and $50 \mathrm{ml}$ were propounded in a conical centrifuge tube. The frozen vial of giant cells was thawed in a $37^{\circ} \mathrm{C}$ water bath to that point that it was possible to decant the cells into the RPMI (a rest of ice in the tube is necessary). The cells were decanted into the RPMI medium and centrifuged at $1200 \mathrm{rpm}$ for $5 \mathrm{~min}$. The resultant cell pellet was subsequently washed with RPMI 1640 four times. The yield of isolated cells 
was re-suspended and seeded on the day 10 CAM $(20 \mu \mathrm{l}$ each).

\section{The chick chorio-allantoic membrane assay}

Fertilized white leghorn chicken eggs (Valo-SPF eggs, Lohmann Tierzucht GmbH, Cuxhaven, Germany) were incubated at a humidity of $70 \%$ and $37^{\circ} \mathrm{C}$. At embryonic day $3,2-3 \mathrm{ml}$ of albumen were removed with a syringe, thus allowing detachment of the embryo and a small window was cut into the eggshell. After verification of normal development of the embryo the window was sealed with tape. After 10 days of incubation small plastic rings made out of Thermanox ${ }^{\mathrm{TM}}$ cover discs were placed on the CAM. After gentle laceration of the CAM surface $20 \mu \mathrm{l}$ of re-suspended tumor suspension were deposited into the rings. For the controls only $20 \mu \mathrm{l}$ of RPMI was used.

Until day 16 CAMs were examined and photographed in ovo with a digital camera (Olympus E330) attached to a stereomicroscope. All embryos that died before day 16 were excluded from further analyses. Tumor volumes were estimated by the following formula: $V=4 / 3^{*} \mathrm{p}^{*} \mathrm{r}^{3}(\mathrm{r}$ $=1 / 2 *$ square root of diameter 1 * diameter 2) [31].

For further information of the technique of the CAM assay see instructional videos in the 'additional files' section (Additional files 2, 3, 4, 5, 6 and 7).

\section{Histology and Immunohistochemistry}

At embryonic day 16, (6 days of tumor growth), tumors were fixed in vivo using $4 \%$ paraformaldehyde for 20 min. Tumors were removed and transferred into culture dishes and samples were observed and photographed. Relevant samples were embedded in paraffin and cut into $10 \mu \mathrm{m}$ sections. Tissue sections were stained with hematoxylin-eosin and by immunohistochemistry using an indirect immunoperoxidase technique, with mouse monoclonal antibodies MIB-1, and KPI (both obtained from DAKO-UK) and NCL-CD14 and NCL-CD51 (Novocastra, UK) directed against the proliferation marker Ki67, the macrophage/osteoclast marker CD68, the monocyte/macrophage marker CD14, and the osteoclast marker CD51 (vitronectin receptor) respectively. Results were analyzed by standard light microscopy (Leica DM2500 with Leica EC3 camera).

\section{Interphase fluorescence in situ hybridization (FISH)}

for the positive identification of cells with human origin we performed an interphase FISH using human haploid repeat sequence containing probe sets [34]. These alpha-satellite probes specifically recognize (peri)centromeric sequences of human chromosomes. Based on the size and specificity of these alpha-satellite probes we selected human chromosome 1 (PUC 1.77) and 15 (D15Z1) [35].
Interphase FISH was performed according to previously described protocols on formalin-fixed paraffinembedded tissue slides [36]. Chromosome 1 (detected by FITC, green) and chromosome 15 (detected by $\mathrm{Cy} 3$, red) specific alpha satellite probes were labeled by using standard nick translation procedure, hybridized and analyzed as previously described [37]. All slides were embedded in Citifluor anti-fading solution containing DAPI for visualization of DNA of the interphase nuclei.

\section{Results}

\section{In vivo observation}

All of the ten GCT samples were able to form solid vascularized tumors when grafted to the CAM (Additional file 1, Figure 1 and 2). No significant differences in the growth rate were observed according to the primary lesion. The percentage of tumors after 6 days of growth in living embryos was $86.9 \%$ (60 of 69 ). The overall death rate after grafting of the tumor tissue was 55\% (69 of 125) and was significantly higher $(P=0.001$, Fisher's exact test - Figure 3) than the death rate of the controls, which was $19 \%$ (5 of 26).

$24 \mathrm{~h}$ after grafting of the suspension, a solid tumor became apparent which then progressively further vascularized without significantly increasing in size (Figure $1)$. With the typical yellow-brownish color and the strong vascularization the tumors resembled the macroscopical aspect of GCT during surgery (Figure 2). The overall mean estimated tumor volume was $12.3 \mathrm{~mm}^{3}$ (4.3 - $35.6 \mathrm{~mm}^{3}$, Additional file 1).

\section{Histological and Immunohistochemical findings}

The tumor samples cultured on the CAM contained both (osteoclast-like) giant cell and mononuclear components of GCT (Figure 4). The giant cells reacted for CD68, which is expressed by both macrophages and osteoclasts, and exhibited the typical immunophenotypic profile of osteoclasts, being CD14- and CD51+ (Figure 5); giant cells in GCT exhibit a similar antigenic phenotype $[38,39]$. The mononuclear component contained cells expressing CD68, CD14 and CD51. Giant cells were numerous and widely scattered throughout the original tumors but fewer were noted in tumors cultured on the CAM. Tumor giant cells frequently contained more than five nuclei in the original tumors but were smaller and contained fewer nuclei in the cultured samples. The tumors appear to grow on the membrane rather than invade it, producing an implant-like rather than infiltrative growth pattern. Vessels were recruited from the CAM to vascularize the tumor. Ki-67 revealed a very low proliferating fraction (less than $1 \%$ ) of cells. The tumors contained a background chronic inflammatory cell infiltrate including lymphocytes and plasma cells. 


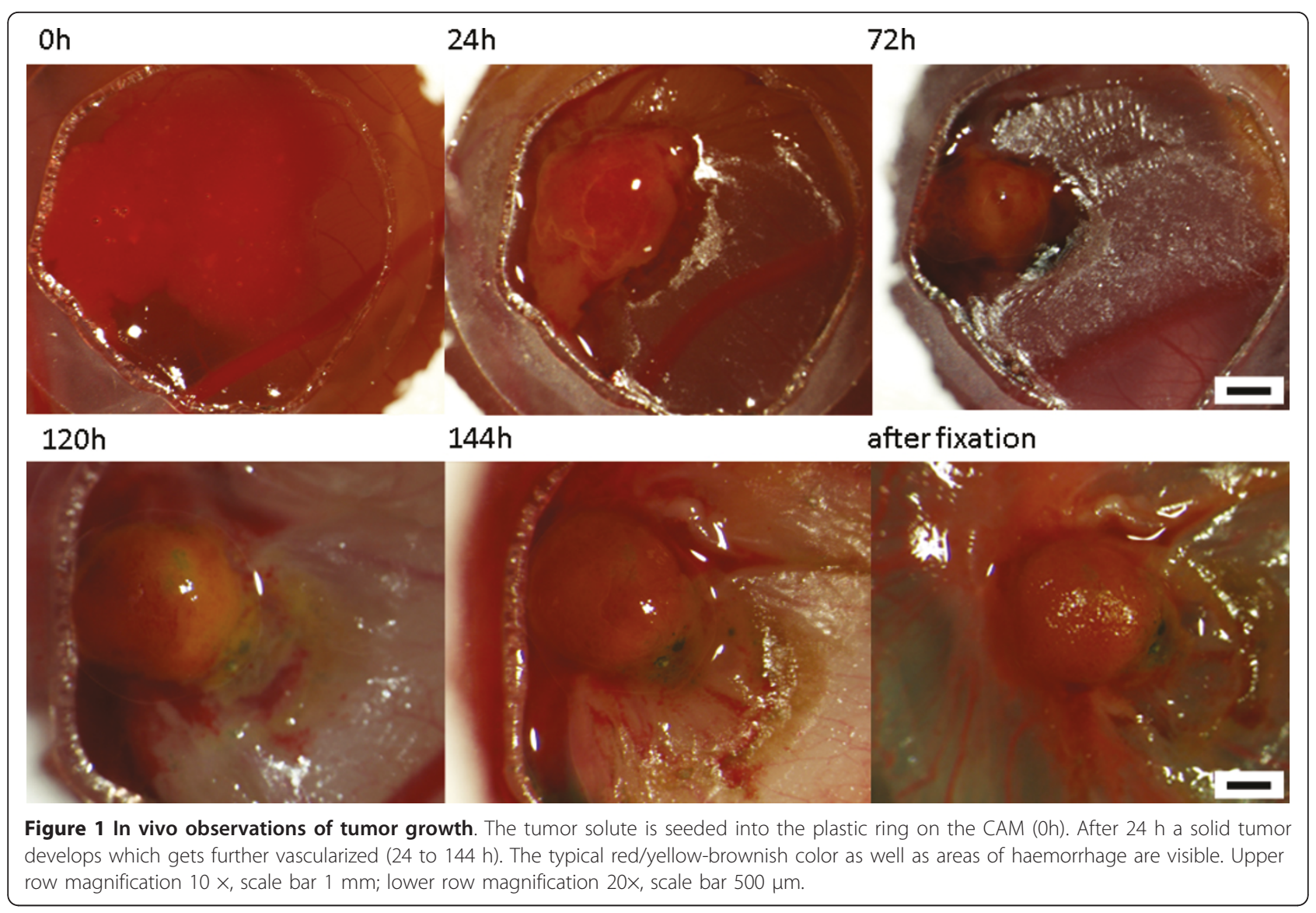

Interphase fluorescence in situ hybridization (FISH)

For the discrimination between the human and chicken cells, we performed interphase FISH using human alpha-satellite probes specific to the heterochromatic region of chromosome 1q12 and the (peri)centromeric region of chromosomes 15 . The two color labeling of these two probes allows the identification of human cells with FISH signals while chicken cells would be stained with DAPI only. The use of a similar approach to discriminate between human and mouse cells have

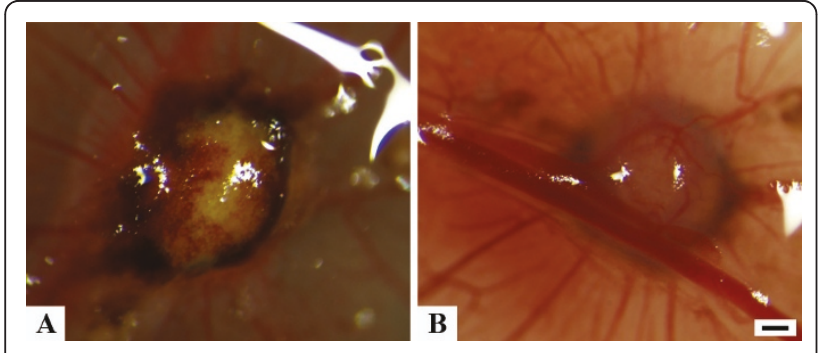

Figure 2 Photographs of day 6 tumor. Another example of a GCT grown on the CAM. Note the typical yellow-brownish color in $\mathbf{A}$ and the strong vascularization of the tumor when the CAM is turned upside down after fixation in B. Magnification $40 \times$, scale bar $250 \mu \mathrm{m}$. been shown by us earlier [34]. Despite the very strong auto-fluorescence coming from extracellular matrix material of the CAM, a clear recognition of the FISH positive human cells were possible (Figure 6). FISH image using two human centromeric probes (red, green)

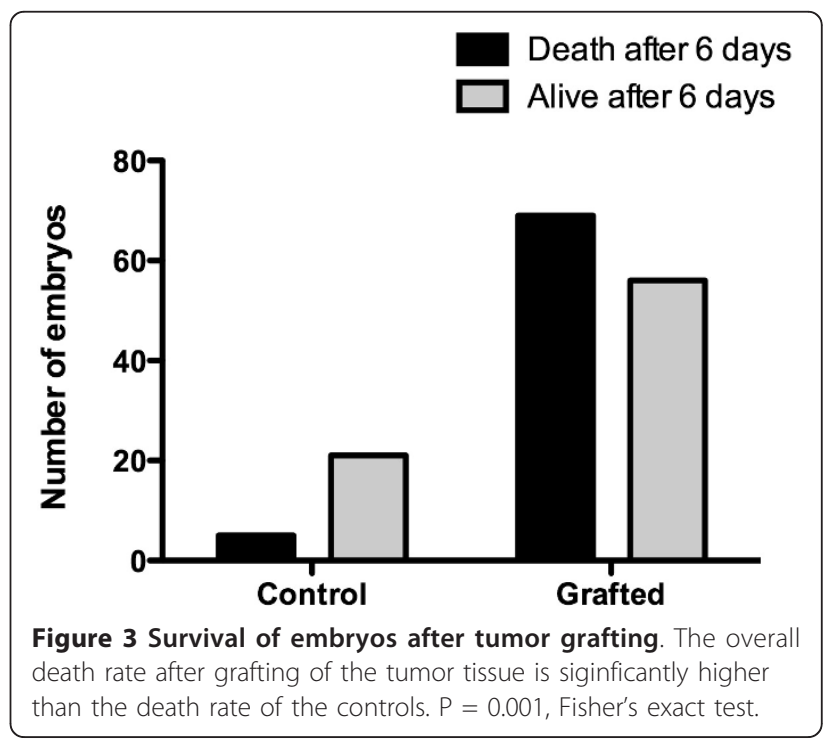




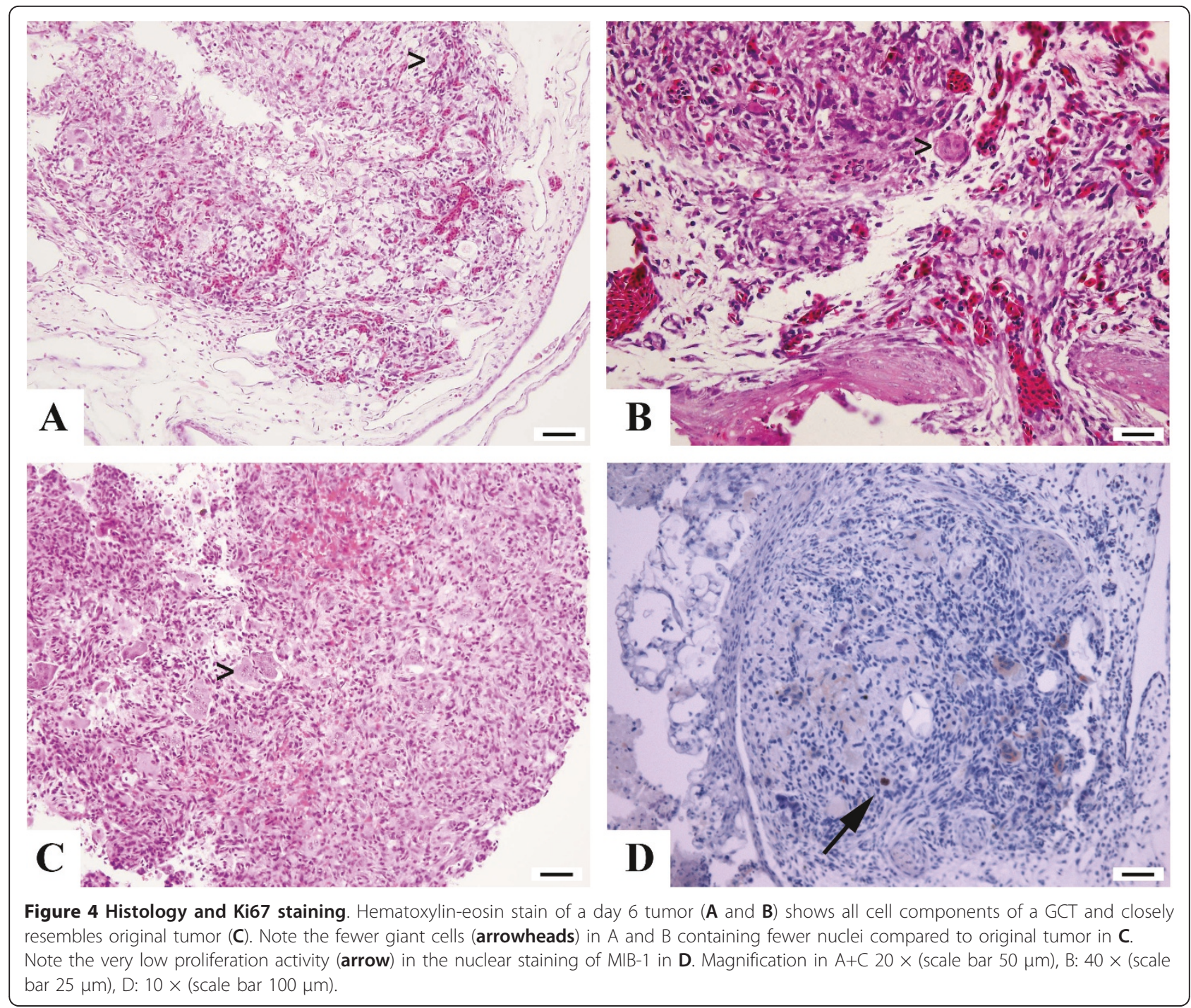

showed that there was no cross reactivity between human and chicken centromeres. There was no signal in the CAM nor in the remaining chicken erythrocytes in the tumor nor in the vascular endothelium (Figure 6B). The giant cells were positive for FISH indicating that they were of human origin.

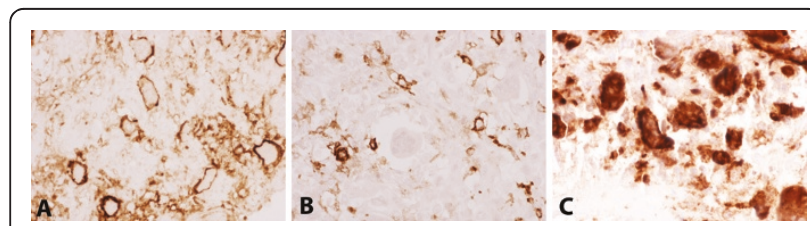

Figure $\mathbf{5}$ Immunophenotypic profile of giant cells. Typical immunophenotypic profile of osteoclasts, being CD51 + (A) and CD14 - (B). Giant cells reacted for CD68 (C), which is expressed by both macrophages and osteoclasts. Magnification $400 \times$.

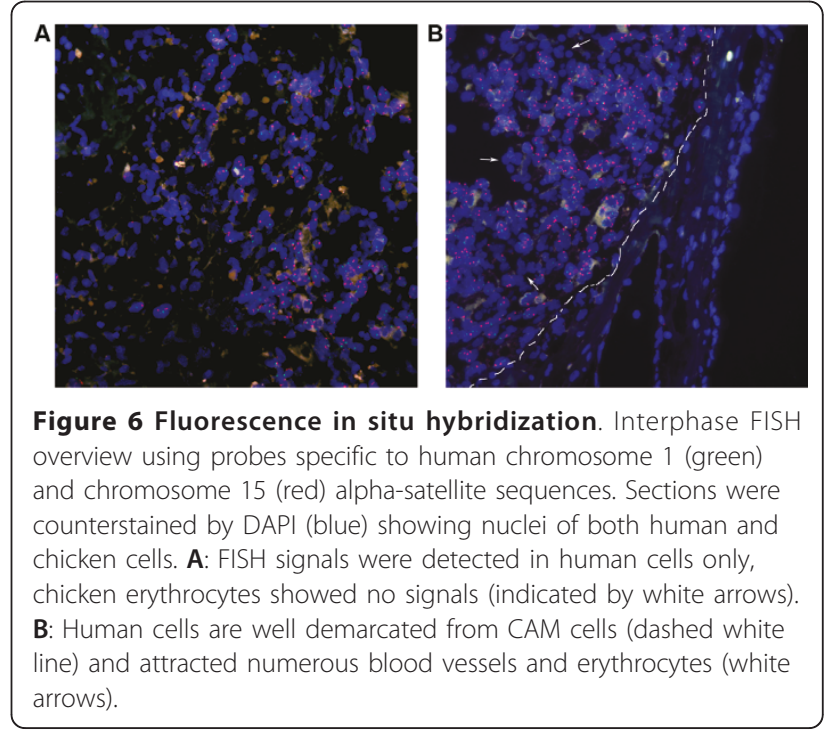




\section{Discussion}

GCT is a locally aggressive primary tumor of bone that commonly recurs and in some cases can be life threatening [40]. Control of tumor growth and intervention to reduce complications such as the development of pulmonary metastases has hitherto not been possible $[1,41]$. The major problem in GCT research is the lack of animal models in which to study GCT growth and pathobiology. Although mononuclear stromal cells can be cultured from GCT, other significant cellular components, notably macrophages and giant cells, do not remain in culture after passaging $[42,43]$. Due to these difficulties, very little is known on the pathobiology of this particular tumor.

The CAM assay is an established in vivo model to study angiogenesis [44]. It is characterized by several advantages such as easy accessibility and relatively simple and cost effective experimental approach. Despite its natural immunodeficient environment (for review see [45]) the CAM assay is still rarely used for tumor grafting. There are reports about the use of the CAM assay as a reliable model to study tumors such as glioblastoma [31], prostatic cancer [46], and melanoma [47], but compared to murine models of tumor growth these are relatively rare. Reports of the use of the CAM assay for establishment of human bone and soft tissue tumors are largely anecdotal $[48,49]$.

Recently, we established the CAM assay for human osteosarcoma cell lines and were able to show that the MNNG-HOS, U2OS and SAOS cell lines consistently developed vascularized tumors that simulated key features of human osteosarcoma growth such as angiogenesis, necrosis and hemorrhage [33]. Compared to tumor formation with osteosarcoma cell lines, where the number of successful implanted tumors was around 50\%, the number of tumors which resulted from suspensions of GCTs seeded on the CAM was nearly $90 \%$ (60 of 69). However, the overall embryonic mortality rate after tumor grafting was 55\% (69 of 125); this was higher than in the previous osteosarcoma study where there was an embryonic mortality rate of $38 \%$ ( 58 of 152) [33]. The underlying reasons for this difference remain speculative, but it is possible that the mortality rate may correlate with tumor (graft) and host interactions; death might be caused by tumor cell dissemination directly or via secretion of specific factors causing blood coagulation. Metabolic stress such as hypoxia and/or serum deprivation [50], may occur in the tumors grafted to the CAM and might induce tumor cells to secrete such molecules.

One theory of GCT lung metastasis formation is that tumor cells invade blood vessels and are disseminated via the blood stream, finally implanting in the lungs. Following implantation, GCTs become established by inducing angiogenesis and further vascularization. The cultured GCTs in our model appeared to grow on the CAM and showed some morphological resemblance to metastatic GCT lung nodules. Although the tumors which grew on the CAM contained all the cellular components of GCT, including stromal cells, macrophages and multinucleated osteoclast-like giant cells, the latter were generally less numerous than in the original tumor, a morphological finding which has been noted in GCT lung nodules [51]. Areas of necrosis and haemorrhage as well as extensive vascularization were present in the tumors grown on the CAM, all features which are typical for GCT. The Ki67 staining demonstrated a very low proliferation rate, in contrast to the original tumors. This might be due to the short time span (only 6 days) of tumor growth. Thus the model would appear to simulate the early phase of tumor seeding, one of the initial steps in the development of a metastasis or local recurrence.

The FISH analysis provided evidence that the experimental GCTs on the CAM are hybrid tumors composed of human graft and chicken host (vasculature) cells. Therefore the model might allow further studies clarifying these crucial steps of angiogenesis and tumor invasion and metastasis which are promising targets for new drugs against solid tumors $[52,53]$. As an example it might be possible to develop new antitumor drugs by simultaneous measuring of gene expression using Affymetrix chicken GeneChips and human GeneChips in the tumor cells as well as in newly formed blood vessels, as has been shown for pancreatic adenocarcinoma [32]. This model represents an excellent alternative to the commonly used animal models. It is cost effective and fulfills the recommendations of an ethically appreciable use of live animals in cancer research [54]. The fact that tumors were grown from a frozen cell suspension will also favor exchange of material between different centres, an important point given the rarity of GCT.

The typical GCT can usually be locally controlled by intralesional curettage or surgical removal. The treatment options for complicated cases, such as GCT with pulmonary metastases or GCT arising in a surgically inaccessible site, are limited. To date only a few promising therapies have been developed for adjuvant use in these cases. The few publications that exist on systemic treatment of GCT have focused on inhibition of osteoclastic bone resorption with bisphosphonates or disruption of the RANK/RANKL pathway of osteoclast formation with specific antibodies such as denosumab $[28,55]$. The limitation of this treatment is that only osteoclasts are inhibited, whereas the proliferating neoplastic stromal cells are mainly unaffected. Thus these treatments might only have a short term effect. Use of the CAM assay should permit the effect of therapeutic 
agents on both stromal and giant cell components of GCT to be studied in greater detail; this model should also facilitate further molecular characterization of the cellular components of this rare tumor.

\section{Conclusions}

A reliable protocol for grafting of human GCT onto the chick chorio-allantoic membrane is established. This is the first in vivo model for giant cell tumors of bone which opens new perspectives to study this disease and to test new therapeutical agents.

\section{Additional material}

Additional file 1: Table 1. Information on patients, anatomical localization of tumor, mortality/growth rate and tumor size. $\mathrm{M}=$ male, $\mathrm{F}$ $=$ Female, prox $=$ proximal, dist $=$ distal, $\mathrm{R}=$ Recurrence, $\mathrm{V} \mathrm{mm}^{3}=$ mean tumor volume calculated by $V=4 / 3^{*} \mathrm{p}^{*} \mathrm{r}^{3}(r=1 / 2 *$ square root of diameter $1 *$ diameter 2), SD = standard deviation.

Additional file 2: Opening of the eggs. Video showing the process of opening of the egg.

Additional file 3: Preparation of plastic rings. Video demonstrating the preparation of the plastic rings.

Additional file 4: Placement of the plastic ring on the CAM. Video showing the placement of the plastic ring on the CAM.

Additional file 5: Gentle laceration of the CAM surface. Video showing the process of gentle laceration of the CAM surface.

Additional file 6: Grafting of the tumor cells. Video demonstrating the technique of tumor cell grafting.

Additional file 7: Fixation and further processing of the tumor tissue. Video demonstration the method of fixation and preparation of the tissue for further processing.

\section{Acknowledgements}

This work was supported by EuroBoNet, a sixth framework Network of Excellence for studying pathology and genetics of bone tumors. None of the authors has professional and financial affiliations that may be perceived to have biased the presentation. There is no conflict of interest.

\section{Author details}

'Department of Trauma and Orthopedic Surgery, University of WittenHerdecke, Cologne-Merheim Medical Center, Ostmerheimer Str., 200, 51109 Cologne, Germany. ${ }^{2}$ Department of Orthopedic Surgery, University of Muenster, Albert-Schweitzer-Str. 33, 48149 Muenster, Germany. ${ }^{3}$ GerhardDomagk-Institute of Pathology, University of Muenster, Domagkstr. 17, 48149 Muenster, Germany. ${ }^{4}$ Department of Pathology, Leiden University Medical Center, Albinusdreef 2, 2300 RC, Leiden, The Netherlands. ${ }^{5}$ Department of Molecular Cell Biology, Leiden University Medical Center, Einthovenweg 20, 2300 RC, Leiden, The Netherlands. ' Department of Medicine, Hematology and Oncology, University of Muenster Domagkstrasse 3, 48149 Muenster, Germany. ${ }^{7}$ Institute of Pathology, Klinikum Hanau GmbH, Leimenstr. 20, 63450 Hanau am Main, Germany. ${ }^{8}$ Department of Pathology, Nuffield Orthopaedic Centre, University of Oxford, Oxford OX3 7LD, UK. ${ }^{9}$ Institute of Pathology, Husener Str. 46 a 33098 Paderborn, Germany. ${ }^{10}$ INSERM U1029, Avenue des Facultés, Bâtiment B2, 33405 Talence cedex, France. ${ }^{11}$ University Bordeaux 1, Avenue des Facultés, Bâtiment B2, 33405 Talence cedex, France.

\section{Authors' contributions}

$M B, A N, N A, K S$, and $M H$ designed experiments and wrote the manuscript. $M B, A N, K A, K S, K A$, and $H B$ conducted the experiments. $M B$, and $G G$ collected the patient data and performed the surgeries. CA, NA and HB performed the histology and immunohistochemistry. $\mathrm{KS}$, and $\mathrm{PH}$ performed the FISH analysis. MB and $\mathrm{MH}$ developed the ideas, NA and $\mathrm{PH}$ corrected and edited the manuscript. All authors have read and approved the final manuscript.

\section{Competing interests}

The authors declare that they have no competing interests.

Received: 16 December 2010 Accepted: 13 June 2011

Published: 13 June 2011

\section{References}

1. Balke M, Schremper L, Gebert C, Ahrens H, Streitbuerger A, Koehler G, Hardes J, Gosheger G: Giant cell tumor of bone: treatment and outcome of 214 cases. J Cancer Res Clin Oncol 2008, 134:969-978.

2. Campanacci M, Baldini N, Boriani S, Sudanese A: Giant-cell tumor of bone. J Bone Joint Surg Am 1987, 69:106-114.

3. Freyschmidt J, Ostertag H, Jundt G: Knochentumoren. 2. Auflage. Berlin, Heidelberg, New York, Tokio, Springer 1998, 611-649.

4. Carrasco CH, Murray JA: Giant cell tumors. Orthop Clin North Am 1989, 20:395-405.

5. Salzer-Kuntschik M: [Differential diagnosis of giant cell tumor of bone] Verh Dtsch Ges Pathol 1998, 82:154-159.

6. Campanacci M: Bone and Soft Tissue Tumors. New York: Springer 1990, 117-151.

7. Larsson SE, Lorentzon R, Boquist L: Giant-cell tumor of bone. A demographic, clinical, and histopathological study of all cases recorded in the Swedish Cancer Registry for the years 1958 through 1968. J Bone Joint Surg Am 1975, 57:167-173.

8. Schwartz HS: Update on giant cell tumor of bone. Compr Ther 1998, 24:488-493.

9. Enneking WF: A system of staging musculoskeletal neoplasms. Clin Orthop Relat Res 1986, 9-24.

10. Masui F, Ushigome S, Fujii K: Giant cell tumor of bone: a clinicopathologic study of prognostic factors. Pathol Int 1998, 48:723-729.

11. Turcotte RE, Wunder JS, Isler MH, Bell RS, Schachar N, Masri BA, Moreau G, Davis AM: Giant cell tumor of long bone: a Canadian Sarcoma Group study. Clin Orthop Relat Res 2002, 248-258.

12. Lausten $G S$, Jensen $P K$, Schiodt $T$, Lund $B$ : Local recurrences in giant cell tumour of bone. Long-term follow up of 31 cases. Int Orthop 1996, 20:172-176.

13. Moskovszky L, Szuhai K, Krenacs T, Hogendoorn PC, Szendroi M, Benassi MS, Kopper L, Fule T, Sapi Z: Genomic instability in giant cell tumor of bone. A study of 52 cases using DNA ploidy, relocalization FISH, and arrayCGH analysis. Genes Chromosomes Cancer 2009, 48:468-479.

14. Werner M: Giant cell tumour of bone: morphological, biological and histogenetical aspects. Int Orthop 2006, 30:484-489.

15. Wulling M, Engels $C$, Jesse N, Werner M, Delling G, Kaiser E: The nature of giant cell tumor of bone. J Cancer Res Clin Oncol 2001, 127:467-474.

16. Lindeman JH, Hanemaaijer R, Mulder A, Dijkstra PD, Szuhai K, Bromme D, Verheijen $\mathrm{JH}$, Hogendoorn PC: Cathepsin $\mathrm{K}$ is the principal protease in giant cell tumor of bone. Am J Pathol 2004, 165:593-600.

17. Forsyth RG, De Boeck G, Baelde JJ, Taminiau AH, Uyttendaele D, Roels $H$, Praet MM, Hogendoorn PC: CD33+ CD14- phenotype is characteristic of multinuclear osteoclast-like cells in giant cell tumor of bone. J Bone Miner Res 2009, 24:70-77.

18. Forsyth RG, De Boeck G, Bekaert S, De Meyer T, Taminiau AH, Uyttendaele D, Roels H, Praet MM, Hogendoorn PC: Telomere biology in giant cell tumour of bone. J Pathol 2008, 214:555-563.

19. Blackley HR, Wunder JS, Davis AM, White LM, Kandel R, Bell RS: Treatment of giant-cell tumors of long bones with curettage and bone-grafting. $J$ Bone Joint Surg Am 1999, 81:811-820.

20. Malek F, Krueger P, Hatmi ZN, Malayeri AA, Faezipour H, O'Donnell RJ: Local control of long bone giant cell tumour using curettage, burring and bone grafting without adjuvant therapy. Int Orthop 2006, 30:495-498.

21. Rock MG, Pritchard DJ, Unni KK: Metastases from histologically benign giant-cell tumor of bone. J Bone Joint Surg Am 1984, 66:269-274.

22. Siebenrock KA, Unni KK, Rock MG: Giant-cell tumour of bone metastasising to the lungs. A long-term follow-up. J Bone Joint Surg Br 1998, 80:43-47

23. Dominkus $M$, Ruggieri $P$, Bertoni F, Briccoli A, Picci $P$, Rocca M, Mercuri M Histologically verified lung metastases in benign giant cell tumours-14 cases from a single institution. Int Orthop 2006, 30:499-504. 
24. Cheng JC, Johnston JO: Giant cell tumor of bone. Prognosis and treatment of pulmonary metastases. Clin Orthop Relat Res 1997, 205-214.

25. Sakkers RJ, van der Heul RO, Kroon HM, Taminiau AH, Hogendoorn PC: Late malignant transformation of a benign giant-cell tumor of bone. A case report. J Bone Joint Surg Am 1997, 79:259-262.

26. Cheng $Y Y$, Huang $L$, Lee $K M$, Xu JK, Zheng MH, Kumta SM: Bisphosphonates induce apoptosis of stromal tumor cells in giant cell tumor of bone. Calcif Tissue Int 2004, 75:71-77.

27. Tse LF, Wong KC, Kumta SM, Huang L, Chow TC, Griffith JF: Bisphosphonates reduce local recurrence in extremity giant cell tumor of bone: a case-control study. Bone 2008, 42:68-73.

28. Thomas D, Henshaw R, Skubitz K, Chawla S, Staddon A, Blay JY, Roudier M, Smith J, Ye Z, Sohn W, et al: Denosumab in patients with giant-cell tumour of bone: an open-label, phase 2 study. Lancet Oncol 2010

29. DeFouw DO, Rizzo VJ, Steinfeld R, Feinberg RN: Mapping of the microcirculation in the chick chorioallantoic membrane during normal angiogenesis. Microvasc Res 1989, 38:136-147.

30. Rahn H, Paganelli CV, Ar A: The avian egg: air-cell gas tension, metabolism and incubation time. Respir Physiol 1974, 22:297-309.

31. Hagedorn M, Javerzat S, Gilges D, Meyre A, de Lafarge B, Eichmann A, Bikfalvi A: Accessing key steps of human tumor progression in vivo by using an avian embryo model. Proc Natl Acad Sci USA 2005, 102:1643-1648.

32. Dumartin L, Quemener C, Laklai H, Herbert J, Bicknell R, Bousquet C, Pyronnet S, Castronovo V, Schilling MK, Bikfalvi A, Hagedorn M: Netrin-1 mediates early events in pancreatic adenocarcinoma progression, acting on tumor and endothelial cells. Gastroenterology 138:1595-1606, 1606 e1591-1598.

33. Balke M, Neumann A, Kersting C, Agelopoulos K, Gebert C, Gosheger G, Burger $\mathrm{H}$, Hagedorn M: Morphologic characterization of osteosarcoma growth on the chick chorioallantoic membrane. BMC Res Notes 2010, 3:58.

34. Smits AM, van Laake LW, den Ouden K, Schreurs C, Szuhai K, van Echteld CJ, Mummery CL, Doevendans PA, Goumans MJ: Human cardiomyocyte progenitor cell transplantation preserves long-term function of the infarcted mouse myocardium. Cardiovasc Res 2009, 83:527-535.

35. Pajor L, Szuhai K, Mehes G, Kosztolanyi G, Jakso P, Lendvai G, Szanyi I, Kajtar P: Combined metaphase, interphase cytogenetic, and flow cytometric analysis of DNA content of pediatric acute lymphoblastic leukemia. Cytometry 1998, 34:87-94

36. Rossi S, Szuhai K, ljszenga M, Tanke HJ, Zanatta L, Sciot R, Fletcher CD, Dei Tos AP, Hogendoorn PC: EWSR1-CREB1 and EWSR1-ATF1 fusion genes in angiomatoid fibrous histiocytoma. Clin Cancer Res 2007, 13:7322-7328.

37. Szuhai K, Bezrookove V, Wiegant J, Vrolijk J, Dirks RW, Rosenberg C, Raap AK, Tanke HJ: Simultaneous molecular karyotyping and mapping of viral DNA integration sites by 25 -color COBRA-FISH. Genes Chromosomes Cancer 2000, 28:92-97.

38. Athanasou NA, Quinn J: Immunophenotypic differences between osteoclasts and macrophage polykaryons: immunohistological distinction and implications for osteoclast ontogeny and function. J Clin Pathol 1990, 43:997-1003.

39. Lau YS, Sabokbar A, Gibbons CL, Giele H, Athanasou N: Phenotypic and molecular studies of giant-cell tumors of bone and soft tissue. Hum Pathol 2005, 36:945-954.

40. Balke M, Ahrens H, Streitbuerger A, Koehler G, Winkelmann W, Gosheger G, Hardes J: Treatment options for recurrent giant cell tumors of bone. J Cancer Res Clin Oncol 2008, 135:149-158.

41. Ghert MA, Rizzo M, Harrelson JM, Scully SP: Giant-cell tumor of the appendicular skeleton. Clin Orthop Relat Res 2002, 201-210.

42. Kito M, Moriya H, Mikata A, Harigaya K, Takenouchi T, Takada N, Tatezaki S, Umeda T: Establishment of a cell line from a human giant cell tumor of bone. Clin Orthop Relat Res 1993, 353-360.

43. Oreffo RO, Marshall GJ, Kirchen M, Garcia C, Gallwitz WE, Chavez J, Mundy GR, Bonewald LF: Characterization of a cell line derived from a human giant cell tumor that stimulates osteoclastic bone resorption. Clin Orthop Relat Res 1993, 229-241.

44. Hagedorn M, Balke M, Schmidt A, Bloch W, Kurz H, Javerzat S, Rousseau B, Wilting J, Bikfalvi A: VEGF coordinates interaction of pericytes and endothelial cells during vasculogenesis and experimental angiogenesis. Dev Dyn 2004, 230:23-33.
45. Hagedorn M, Wilting J: Chick chorioallantoic membrane assay: growth factor and tumor-induced angiogenesis and lymphangiogenesis Berlin, Heidelberg, Germany: Springer; 2004

46. Kunzi-Rapp K, Genze F, Kufer R, Reich E, Hautmann RE, Gschwend JE: Chorioallantoic membrane assay: vascularized 3-dimensional cell culture system for human prostate cancer cells as an animal substitute model. J Urol 2001, 166:1502-1507.

47. MacDonald IC, Schmidt EE, Morris VL, Chambers AF, Groom AC: Intravital videomicroscopy of the chorioallantoic microcirculation: a model system for studying metastasis. Microvasc Res 1992, 44:185-199.

48. Deryugina El, Zijlstra A, Partridge JJ, Kupriyanova TA, Madsen MA, Papagiannakopoulos T, Quigley JP: Unexpected effect of matrix metalloproteinase down-regulation on vascular intravasation and metastasis of human fibrosarcoma cells selected in vivo for high rates of dissemination. Cancer Res 2005, 65:10959-10969.

49. Tsuchiya Y, Endo Y, Sato H, Okada Y, Mai M, Sasaki T, Seiki M: Expression of type-IV collagenases in human tumor cell lines that can form liver colonies in chick embryos. Int J Cancer 1994, 56:46-51.

50. Denko NC, Giaccia AJ: Tumor hypoxia, the physiological link between Trousseau's syndrome (carcinoma-induced coagulopathy) and metastasis. Cancer Res 2001, 61:795-798.

51. Alberghini M, Kliskey $K$, Krenacs T, Picci P, Kindblom L, Forsyth R, Athanasou NA: Morphological and immunophenotypic features of primary and metastatic giant cell tumour of bone. Virchows Arch 2010 456:97-103.

52. Almog $N$, Henke V, Flores L, Hlatky L, Kung AL, Wright RD, Berger R, Hutchinson L, Naumov GN, Bender E, et al: Prolonged dormancy of human liposarcoma is associated with impaired tumor angiogenesis. Faseb J 2006, 20:947-949.

53. Ma WW, Adjei AA: Novel agents on the horizon for cancer therapy. CA Cancer J Clin 2009, 59:111-137.

54. Russell WMS, Burch RL: The Principles of Humane Experimental Technique. New edition edition. Potters Bar, UK: Universities Federation for Animal Welfare (UFAW); 1992.

55. Balke M, Campanacci L, Gebert C, Picci P, Gibbons M, Taylor R, Hogendoorn P, Kroep J, Wass J, Athanasou N: Bisphosphonate treatment of aggressive primary, recurrent and metastatic Giant Cell Tumour of Bone. BMC Cancer 2010, 10:462.

\section{Pre-publication history}

The pre-publication history for this paper can be accessed here: http://www.biomedcentral.com/1471-2407/11/241/prepub

doi:10.1186/1471-2407-11-241

Cite this article as: Balke et al:: A short-term in vivo model for giant cell tumor of bone. BMC Cancer 2011 11:241.

\section{Submit your next manuscript to BioMed Central and take full advantage of:}

- Convenient online submission

- Thorough peer review

- No space constraints or color figure charges

- Immediate publication on acceptance

- Inclusion in PubMed, CAS, Scopus and Google Scholar

- Research which is freely available for redistribution

Submit your manuscript at www.biomedcentral.com/submit
C Biomed Central 